\title{
Role of Ayurvedic parasurgical procedures in the successful acceptance of graft in non-healing venous ulcer- A Case Study.
}

\section{Samiksha Madhukar Bhuran ${ }^{* 1}$, Ashok Pawar ${ }^{2}$}

1. PG Scholar.

2. Associate Professor

Shalyatantra Dept, M. E. S. Ayurved Mahavidyalaya, Ghanekhunt, Maharashtra.

*Corresponding Author: email id- drsamikshasurgery66@gmail.com

\begin{abstract}
-
Venous ulcer is one of the common and difficult to treat cases as it has a high recurrence rate and non-healing nature, failure of graft acceptance, and many aggravating factors. Treatment is mosty surgical and not affordable to everyone. Many theories were proposed to find the exact cause of the condition and yet it is uncertain. Ayurvedic protocol based treatments helps in treating such conditions thereby improving the agni, bala, satva of such patients along with successful healing. As the treatment is time taking and the patient already has an idea about it, stepwise treatment plays a major role and hence it is a topic were observational studies are required. This paper highlights the role of Ayurvedic protocol in a complicated case with previous surgical histories, failure, and co morbid where amputation and failure of graft was already suggested to the patient previously.
\end{abstract}

\section{KEYWORDS-}

venous ulcer, leech therapy, vranadhoopana, non-healing ulcer, siragata dushta vrana.

\section{ANTRODUCTION-}

Treating varicose ulcer without recurrence has got very less success rate and many patients seeking treatment are seen with history of relapse and nonhealing wound. Some commenter's consider it under siragata dushta vrana .The overall incident rate in male is $0.76 \%$ and $1.42 \%$ in the female population ${ }^{1}$.At present, ambulatory venous hypertension is the only accepted cause of ulceration. It is important to try and define the exact mechanism of ulcer development. The venous hypertension may be the result of primary valve incompetence of the saphenous veins, incompetence of the perforating veins or incompetence or obstruction of the deep veins $^{2}$.Venous disease is responsible for between $60 \%$ and $70 \%$ of all ulcers in 
the lower $\mathrm{leg}^{3}$. Successful treatment is most frequently that of non-operative measures to improve venous return. When this has restored healthy granulation tissue to the base of a large ulcer but re-epithelialization from the edges is slow, a split skin graft can speed the final healing ${ }^{4}$. In sushrut samhita, 60 upakramas and their individual significance is mentioned ${ }^{5}$. On the other hand, basic seven pillars of wound management called as "saptopakrama" are also stated ${ }^{8}$. Carak samhita which contains mainly the internal medicine, have also described 36 upakramas ${ }^{9}$. Proper bandaging techniques depending of type of wounds is also referred from "Agropaharaniya adhyaya" 6. Leech therapy is effectivebuerger's disease and also in other peripheral vascular diseases $^{7}$. Leech therapy is mainly indicated in pitta dosha predominance and raktaj disorders ${ }^{10}$. All these references together have contribute this case.

\section{CASE REPORT-}

57 year old male patient was admitted on 23/12/2020 with progressing gross ulcer over Right lower limb since 9 years, and history of fever, swelling and foul smelling discharge.

\section{P/S/H-}

1) D2- D3 Decompression (Koch's spine) - 22/11/2008.

2) Right leg varicose vein stripping and ligation- 06/01/2017.

P/M/H- No history of diabetes or hypertension.

L/E-
- Gross varicose ulcer above right ankle.

- Irregular margins, sloping edges.

- Necrosed tissue near calf with history of maggots.

- Foul smelling wound with peripheral blackish discoloration.

- Dorsalis pedis+.

\section{The following Ayurvedic protocol was followed:}

1. Vranakarma was done on daily basis in which necrosed tissue and slough was dissected.

2. Vranashodhana taila was used in the dressing.

3. Vranadhoopana was done with coarse powders of:Shunthi (zingiber officinale), Raal (canarium strictum), Agaru (Aquilaria agallocha), Vacha (Acorus Calamus).

alaukavacharana was done after every 3-4 days and it significantly reduced peripheral oedema with discoloration.

5. Jatyadi taila was added for dressing later.

6. After achieving healthy granulation, split thickness skin grafting was done under spinal anaesthesia.

7. Post-operative vranakarma was done with NS, betadine, jatyadi taila and vranashodhan taila in between.

8. Orally, Triphala guggul, chandraprabha vati, gandhak rasayana, varunadi kashayam were given. Antibiotics were given as and when required. 

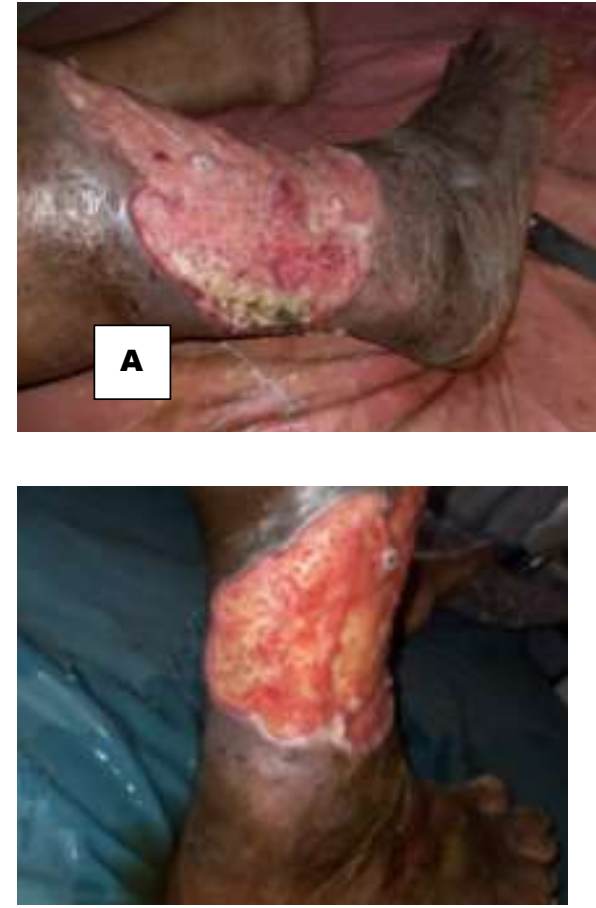

Fig. A: On day 1, when the patient was attented in the opd;

Fig. B: Reduced slough after 4 days (vranashodhana taila used for dressing)
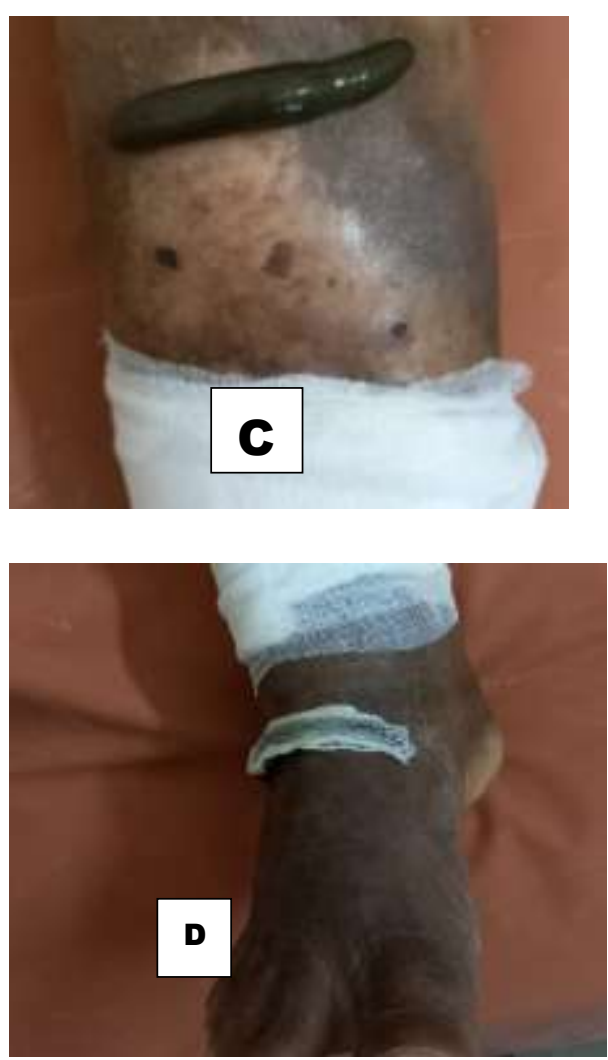

Fig. C: leech therapy along with significant reduction of black discoloration seen around previous leech application spots.

Fig. D: significant decrease in edema over foot due to leech therapy.
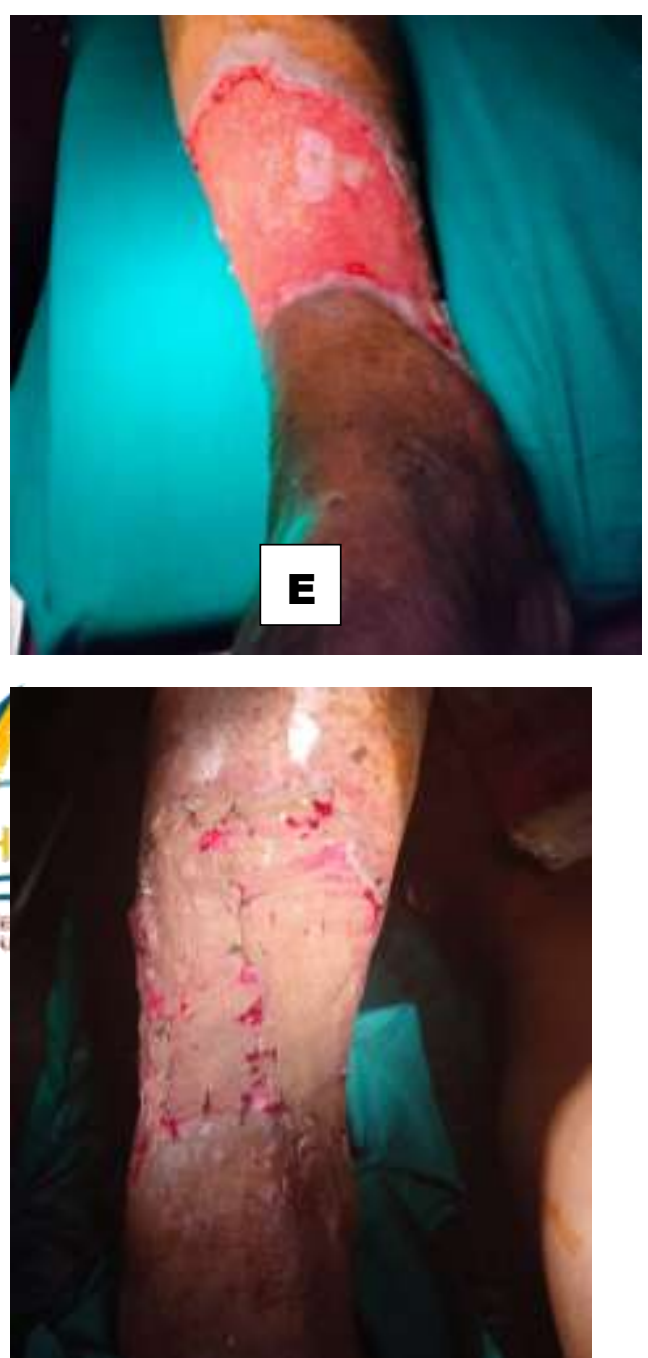

Fig. E: pre-op wound with healthy granulation, reduced edema \& discoloration.

Fig. F: Intra operative status of spilt thickness skin grafting. 

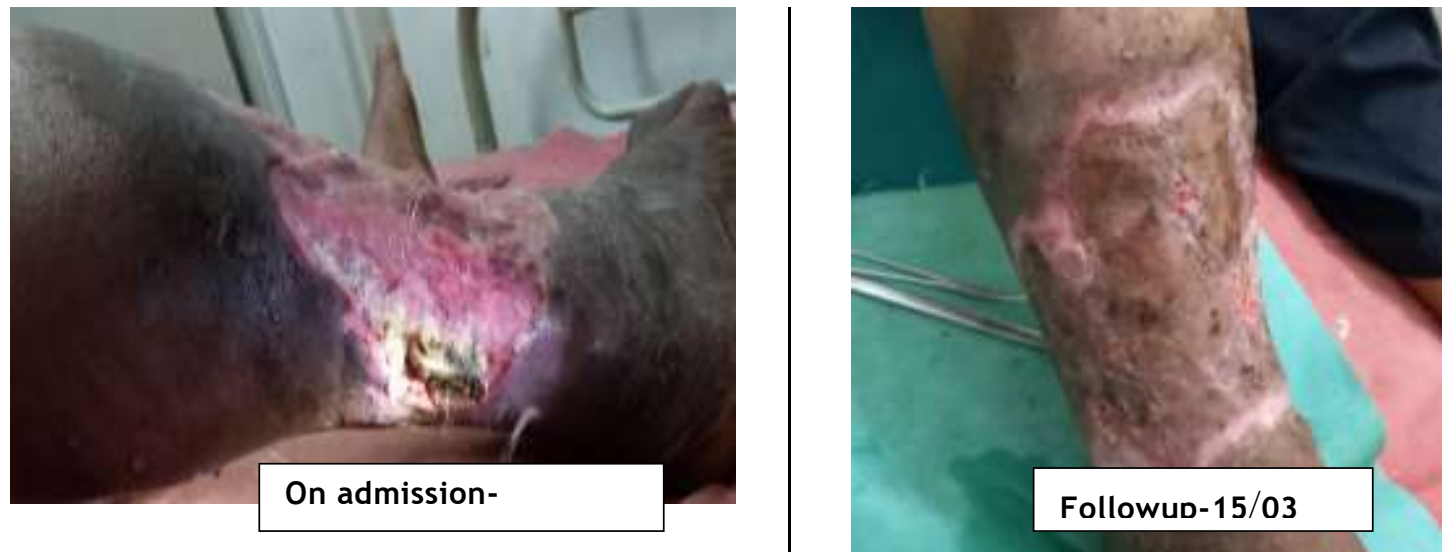

OSERVATIONS-

\begin{tabular}{|c|c|c|c|c|c|}
\hline Lakshanas & $\begin{array}{l}\text { On } \\
\text { admission } \\
23 / 12 / 20\end{array}$ & $\begin{array}{l}\text { During } \\
\text { vranakarma } \\
26 / 12 / 20\end{array}$ & $\begin{array}{l}\text { After } \\
\text { vranadhupana } \\
\mathbf{3 0} / \mathbf{1 2} / \mathbf{2 0}\end{array}$ & $\begin{array}{|lr|}\text { After } & 2 \\
\text { settings } & \text { of } \\
\text { leech therapy }\end{array}$ & $\begin{array}{l}\text { POD 20 } \\
15 / 03 / 21\end{array}$ \\
\hline Pain & +++ & +++ & ++ & + & - \\
\hline Discharge & ++++ & +++ & + & - & - \\
\hline Foul smell & +++ & ++ & - & - & - \\
\hline Edema & +++ & +++ & 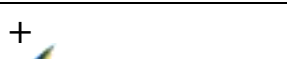 & - & - \\
\hline $\begin{array}{l}\text { Black } \\
\text { discoloration }\end{array}$ & +++ & +++ & & + & + \\
\hline \multicolumn{6}{|c|}{$\begin{array}{l}\text { DISCUSSION- } \\
\text { 1. Raktamokshana which has played a }\end{array} \begin{array}{l}\text { specifically in a vranita. Yava } \\
\text { godhuma, jeerna shali, saktu, mudga, } \\
\text { major role is nothing but type of } \\
\text { 'Apatarpana' which is one of the }\end{array} \begin{array}{l}\text { dadim, patola, karavellaka etc when } \\
\text { major upakramas; hence classical }\end{array}$} \\
\hline
\end{tabular}

2. Vranadhupana which means fumigation using dravyas like ghee, vacha, raal etc as described in texts are responsible for reducing secretions and pain (as dhoopan is mainly indicated in vataj, tivra shoolayukta, sravi vrana).

3. Vranakarma which included lekhana which facilitated granulation formation as superficial adherent slough was removed. Shodhana taila and jatyadi taila dressings made the wound suitable for grafting.

\section{CONCLUSION-}

A complicated case where graft failure and amputatuion was adviced to the patientand hence it took 9 yrs for the patient to take decision of surgery even if there was a history of failure of previous striping and ligation surgery. Ayurvedic parasurgical procedures like vranadhoopana, jalaukavacharana, vrankarma and internal Ayurvedic medicions played a major role in treating the case. Also, wound is always a major concern, but peripheral edema, blackish 
discoloration, foul smell and dicharge significantly reduces and good outcome can be achieved with leech therapy and vranadhupana. When the wound heals completely, sahachara taila dharasweda can be administered which helps in blood circulation and sthanik vata-pitta shaman thereby contributing in the prevention of recurrence.

\section{REFERENCES-}

1. Margolis DJ, Bilker W, Santanna J, Baumgarten M. Venous leg ulcer: incidence and prevalence in the elderly. J Am Acad Dermatol. 2002 Mar;46(3):381-38

2. Burnand $\mathrm{K}$, venous Disorders; Williams N S; Christopher JK; Bailey and love's short practice of surgery; 25 ${ }^{\text {th }}$; London; HodderArnold; 2008; p.934.

3. Burnand $\mathrm{K}$, venous Disorders; Williams N S; Christopher JK; Bafley and love's short practice of surgery; $25^{\text {th }}$; London; HodderArnold; 2008; p.933.

4. W Stuart; operative management of vascular disease, M Farquharson, B Moran; Farquharson's textbook of operative general surgery; $9^{\text {th }}$; Great britan; Hodder Ernold; 2005; p.123.
5. Acharya priyavat sharma; Dr. Anantaram sharma; Sushrut Samhita part- 2 ; Chaukhamba surabharti prakashan, Varanasi; Chikitsasthan; 2015; chapter 1,shlok number 137,138; p. 173.

6. Acharya priyavat sharma,Dr. Anantaram sharma, Sushrut samhita; part- 1 ;chaukhamba surabharti prakashan, Varanasi; sutrasthan, 2015; chapter 18, shlok number:18; p. 154.

7. Kumar Mahesh. Role of Ayurvedic medicines and leech therapy in the management of burger's disease- A case report. $\mathrm{J}$ of Ayurveda and HolMed (JAHM).2014; 2(8):27.

8. Acharya priyavat sharma, Dr. Anantaram sharma; Sushrut samhita part- 1; chaukhambasurabharti prakashan, Varanasi; 2015; sutrasthan; chapter 17; shlok number18; p. 150.

Acharya priyavat sharma, vijay Shankar kale; carak samhita; chaukhamba Sanskrit sansthan; delhi; 2016; 20, 39 -43.

10. Srikantha Murthy KR. Ashtanga Hrudaya, Sutrasthana. 1st ed.Varanasi, India: Krishnadas Academy; 1991:26/49.

Conflict of Interest:

DOI Non https://doi.org/10.52482/ayurline.v5i03.544 Source of funding: Nil

Cite this article:

Role of Ayurvedic parasurgical procedures in the successful acceptance of graft in non-healing venous ulcer- A Case Study. Samiksha Madhukar Bhuran, Ashok Pawar Ayurline: International Journal of Research In Indian Medicine 2021; 5(3):01-05 